3. Мобільний застосунок Mova. Освітній проект «Мова ДНК нації»: сайт. URL: https://ukr-mova.in.ua/blog/pershuj-mobilnujzastosunok-dlya-vuvchennya-ukrayinskoyi-movu. (дата звернення: 12.09.2020).

4. Сорокин Ю., Тарасов Е. Креолизованные тексты и их коммуникативная функція. Оптимизация речового воздействия. Москва: Наука. 1990. С. 180-186.

DOI https://doi.org/10.30525/978-9934-588-80-8-2.53

\title{
FEATURES OF PHYSICAL TRAINING OF STUDENT TOURISTS
}

\author{
Yahotin R. S. \\ Candidate of Pedagogical Sciences, \\ Senior Lecturer at the Department of Physical Culture and Sports \\ Odessa National Academy of Food Technologies \\ Odessa, Ukraine
}

An urgent problem of modern society is the deterioration of the physical condition of the population, including student youth. Scientists in physical education were found that most students have a low level of physical fitness, decreased functional status, physical and mental health [3, p. 111; 7, p. 55].

Active recreation and tourism are becoming increasingly popular in the system of physical education of students, because they are effective and affordable types of physical activity. The variety of forms and means of sports tourism increases the prospects of its use in the fight against the growing hypodynamics of modern man. Sports tourism provides a comprehensive impact on the comprehensive development of youth is a manifestation of a healthy lifestyle and helps to maintain physical performance [1, p. 2-3]. Systematic classes in sports and health tourism cause an increase in the level of functional state of the cardiovascular, respiratory and muscular systems [6, p. 34]. Such positive changes are possible provided that the principles of the theory of sports training are observed, namely: the priority of needs, motives and interests of the individual; regularity; gradualness; accessibility and individualization [5, p. 53]. Significant improvement of students' physical fitness is achieved after the annual cycle of training, which involves participation in 4 training campaigns [1, p. 17]. 
The purpose of the work is to determine the features of physical training of student tourists and to offer a program of their preparation for a sports hiking.

Sports tourism refers to sports that are characterized by active physical activity with the manifestation of physical and volitional qualities. According to its classification, it belongs to the mixed species, and therefore tourists must comprehensively develop their own physical qualities (endurance, strength, coordination, speed, flexibility).

Physical training of tourists is aimed at improving the functional capabilities of the body, the development of their physical qualities, and conditionally, it is divided into general and special.

General physical training (GFT) ensures the harmonious development of human motor abilities, which have a positive effect on the achievements in sports training and the effectiveness of the training process. GFT is the foundation (basis) of tourist training, without the formation of which it is impossible to achieve success in mastering and improving the techniques of various types of tourism. General physical training is especially important in the initial stages of tourism and in the preparatory period of the annual cycle of training of athletes of all qualifications and specializations.

Special physical training (SPT) involves mastering the specific skills required for a particular type of tourism. SPT is focused on the development of individual motor skills and takes into account the peculiarities of the tourist's competitive activity. Of particular importance in the special physical training of tourists is the training of various types of travel with a backpack, overcoming natural obstacles with cargo, as well as exercises of all-around (setting up a tent for speed, tying knots, working with special camping equipment, etc.) [1, p. 10; 2, p. 125; 5 p. 8].

The educational and training process of each year of study of tourist students must consist of one or more macrocycles. In macrocycles there are preparatory, competitive and transitional mesocycles, which reflect the phases of development of sports form: formation, stabilization and temporary loss.

When planning and developing training cycles for student tourists, it is advisable to use the following methods:

1. Uniform characterized by a continuous, long mode of operation with uniform speed or effort. Exercises should be performed with low or medium intensity. For the formation of general endurance, the most common is the use of cyclic exercises lasting at least 30-40 minutes, performed in aerobic mode. 
2. Variable is determined by the consistent variation of the load during the continuous performance of the exercise by dosed changes in speed, pace, range of motion and magnitude of effort.

3. Interval involves performing exercises of standard and variable load with clearly dosed and pre-planned rest intervals. As a rule, the interval of rest between exercises is $1-3 \mathrm{~min}$.

4. The method of circular training involves performing exercises that affect different muscle groups and functional systems such as continuous or interval work in a circle.

5. Competitive method contains specialized exercises in the form of competitions.

6. The game method involves the development of physical qualities in the game, the conditions of constant and largely random change of the game situation [4, p. 40; 5, p. 107].

Below is an approximate plan of monthly preparation (mesocycle) of students for sport hiking.

1 day. Warm-up, walking, running at a medium pace (10-15 min). General developmental exercises in gymnastics, exercises with a skipping rope, long jumps from a place $(20-30 \mathrm{~min}$.). Sports games $-30 \mathrm{~min}$. The final part is walking, breathing exercises, stretching and muscle relaxation exercises (5-10 $\mathrm{min})$.

2 day. Warm-up, running (7-10 min). General developmental exercises 15 min. Exercises with dumbbells, exercises on bars, crossbars -60 min. Sports games $-30 \mathrm{~min}$.

3 day. Training in the form of a one-day hike or orienteering competition with the obligatory mastering of the elements of the chosen type of tourism. Exercise in its volume and intensity should fully correspond to the load planned in the campaign.

The purpose of training students of tourists is to achieve a high level of sportsmanship, which is reflected in the proper technical and tactical, physical and psychological training. Physical training of tourists should take into account the principles of sports training patterns and features of the use of physical activity, recommendations for the duration and intensity of physical activity. This will improve the functionality of the body and the basic physical qualities of tourists, which will help achieve their goals.

The prospect of further research is the development and implementation of a program of pedagogical control tourist students physical condition' using modern electronic devices. 


\title{
References:
}

1. Денисенко I. А. Використання засобів спортивно-оздоровчого туризму в підвищенні фізичного стану студентів 18-19 років: атореф. дис. ... на здобуття наук канд. наук з фізичної культури, фізичного виховання різних верств населення спец. 24.00.02 Дніпро 2014. 22 с.

2. Зеніна I. Особливості фізичної підготовки туристів. Основи спортивного туризму в рекреаційній діяльності. 2016. С. 124-130. http://journals.uran.ua/tourism_kzvsvst/article/view/80175/75740

3. Круцевич Т., Пангелова Н. Сучасні тенденції щодо організації фізичного виховання у вищих навчальних закладах. Спортивний вісник Придніпров'я. 2016. 3. С. 110-114.

4. Чичкан О. А., Кость М. М. Фізичне виховання у схемах: навчально-методичний посіб. Львів: Львівський державний університет внутрішніх справ, 2011. 104 с.

5. Холодов Ж. К. Кузнєцов В. С. Теорія і методика фізичного виховання і спорту. Учеб. посібник для студ. вищ. Навчань закладів. Видавничий центр «Академія», 2000. 480 с.

6. Denisenko IA. The peculiarities of functional state changes of cardiovascular system of girls at the age 18-19 years in the process of practicing sport and health tourism. Physical Education of Students, 5, 32-36. http://dx.doi.org/10.6084/m9.figshare.781289 [in English].

7. Yagotin, R. S., Degtyarenko, T. V., Bosenko, A. I., Plisko, V. I., \& Dolinsky, B. T. (2019). Criterion score of the physical and psychophysiological condition of students in the context of determining their individual adaptability to physical loads. Physical Education of Students, 23(1), 51-57. https://doi.org/10.15561/20755279.2019.0108 [in English].

DOI https://doi.org/10.30525/978-9934-588-80-8-2.54

\section{ЗАСОБИ НАВЧАННЯ УКРАЇНСЬКОЇ МОВИ}

\author{
Яремчук Н. С. \\ кандидатка педагогічних наук, \\ дочентка кафедри украӥнської мови \\ Дніпровський національний університет імені Олеся Гончара \\ м. Дніпро, Україна
}

Метою статті є визначення засобів навчання української мови, що полегшують організацію навчального процесу, забезпечують пізнавальну активність школярів, удосконалюють комунікативні вміння і навички. 